International Research Journal of Engineering, IT \& Scientific Research
Available online at https://sloap.org/journals/index.php/irjeis/
Vol. 5 No. 1, January 2019, pages: 15 26
ISSN: 2454-2261
https://doi.org/10.21744/irjeis.v5n1.586

\title{
Seepage in Soil from the Difference of Water Viscosity Using Geo-Studio SEEP/W Program
}

\author{
I Nyoman Aribudiman ${ }^{a}$ \\ I Wayan Redana ${ }^{b}$ \\ Kadek Diana Harmayani ${ }^{\mathrm{c}}$ \\ Yenni Ciawi $^{\mathrm{d}}$
}

Article history:

Received: 27 July 2018

Accepted: 30 November 2018

Published: 25 January 2019

\section{Keywords:}

leach ate;

saturated/unsaturated;

seepage;

soils;

viscosity;

\begin{abstract}
The soil is an important material for human life. The problem that is often encountered with soil is soil contamination due to the discharge of leachate into the soil. This research aims to observe the influence of leachate viscosity on seepage using Geo-Studio SEEP/W Program. The samples of leachate were taken from ceramic industry and from Suwung landfill site. Soil samples were silty sandy taken from Ida Bagus Oka street, Denpasar, Bali. Seepage modeling in Geo-Studio SEEP/W was conducted on silty sand condition using pure water (without leachate), leachate from ceramic industry, and leachate from Suwung Disposal Site. Seepage modeling on Geo-Studio was conducted on saturated/unsaturated condition. It was found that the leachate viscosity was different each other. The viscosity of leachate from ceramic industry was $0.01366741 \mathrm{~N} \mathrm{~s} / \mathrm{m}^{2}$ and $0.002061309 \mathrm{~N} \mathrm{~s} / \mathrm{m}^{2}$ from Suwung Disposal Site. Due to mixed with leachate, soil hydraulic conductivity decreased from $0.001949 \mathrm{~cm} / \mathrm{s}$ to $0.0001029 \mathrm{~cm} / \mathrm{s}$. The largest discharge and velocity of seepage on silty sand material from Ida Bagus Oka street, Denpasar, obtained by using Geo-Studio SEEP/W Modeling was produced by pure water (without leachate), whereas, the smallest one produced by leachate from Suwung landfill site. The influence of seepage discharge and seepage velocity change on silty sand in Ida Bagus Oka street, Denpasar due to the flow of leachate from ceramic industry and leachate from Suwung Disposal Site against pure water seepage discharge and seepage velocity are $70,573 \%$ and $5,313 \%$.
\end{abstract}

2454-2261 ${ }^{\circledR}$ Copyright 2019. The Author. This is an open-access article under the CC BY-SA license (https://creativecommons.org/licenses/by-sa/4.0/) All rights reserved.

a Engineering Doctorate Program, Civil Engineering Department, Faculty of Engineering, Udayana University, Denpasar, BaliIndonesia

b Lecturer in Civil Engineering Doctorate Program Engineering Department, Faculty of Engineering, Udayana University, Denpasar, Bali-Indonesia

${ }^{c}$ Lecturer in Civil Engineering Doctorate Program Engineering Department, Faculty of Engineering, Udayana University, Denpasar, Bali-Indonesia

d Lecturer in Civil Engineering Doctorate Program Engineering Department, Faculty of Engineering, Udayana University, Denpasar, Bali-Indonesia 


\section{Author correspondence:}

I Nyoman Aribudiman,

Doctorate Candidate, Engineering Doctorate Program, Civil Engineering Department, Faculty of Engineering,

Udayana University, Denpasar, Bali-Indonesia.

Email address: n.aribudiman@gmail.com

\section{Introduction}

The land is a natural material that plays an important role in human life. Problems related to soil are pollution of soil due to waste disposal to the soil. Wastewater may come from waste processed domestic waste or household waste, industrial and leachate waste discharged from waste piles. Most of the residential, industrial and final disposal sites still do not have adequate wastewater treatment plants. As a result, wastewater from processing or activity and piles of waste directly discharged into water bodies or allowed to flow to the ground.

Soil contamination of wastewater affects the soil properties. Huang \& Lu (2014); Sen et al., (2016); Van Olphen \& Hsu (1978), conducted researches on the effects of oil and fat contamination on the limits of clay atterbergs. Prakash \& Arumairaj (2013); Yong et al., (1992), examined the effect of acid and base contamination on the geotechnical properties of clay soil. Ghobadi et al., (2013); Rahman \& Nahar (2015); Spagnoli (2012), Sunil et al., (2006), Tajnin et al., (2014), suggest that changes in water pH will affect clay soil characteristics. Nair \& Philip (2016), in his research, stated that the addition of $25 \% \mathrm{NaOH}$ and $50 \%$ acetic acid in fly ash mixed soil can increase the value of plastic limit and soil liquid limit but reduce the value of compressive strength and soil cohesion. Reddy \& Sivapullaiah (2010); Olgun \& Yildiz (2012); Yunus et al., (2011); and Bakhshipour (2016), conducted a study of the effect of acetic acid on changes in structure and shear strength of the soil. One of the effects of pollution is on the value of permeability. Permeability is defined as the nature of the porous material in which the flow of seepage from the liquid flows through the pores (Hardiyatmo, 2012). Knowledge of seepage and the pattern of water flow in the ground can not be separated from Darcy's law. One of the indicators contained in Darcy's legal equation is the permeability coefficient or seepage coefficient. The seepage coefficient depends on several factors such as the viscosity, the grain size, the pore number, the roughness of the surface grain and the degree of saturation of the soil. So other than the soil type, viscosity or fluid viscosity also affects seepage behavior and water flow patterns in the soil.

This study aims to determine the effect of viscosity of a liquid (wastewater) and soil type to seepage in the soil. The viscosity of a liquid is very influential on the specific gravity and the volume weight of the liquid itself even affects the seepage coefficient or soil hydraulic conductivity. In this study, the soil hydraulic conductivity value of wastewater will be used as one of the parameters to be input on the model created using Geo-Studio Seep/W application and to know the flow that occurs in the model. The results obtained from the analysis using the GeoStudio Seep/W application would be able to explain how the distribution of the rate of seepage of a liquid (wastewater) into the soil. By knowing the seepage discharge of a fluid that seeps into the soil, it can also be calculated the speed of seepage of the fluid into the soil.

\section{Materials and Methods}

\section{Method of Collecting Data and Modeling of Holds in SEEP/W Geo-studio}

There are two types of data in this study namely land data and wastewater data. Land data used is silty sandy land on Ida Bagus Oka street, Denpasar. Some soil parameters needed in this study include soil porosity, filter analysis data to determine the type of soil to be analyzed and soil hydraulic conductivity. Calculation of the value of soil. Equation 1.

$$
w=\frac{n}{(1-n) G s} .
$$

Wastewater used uses leachate from Suwung Landfill and Wastewater from ceramic processing from PT. Cevala Ceramics. Wastewater data includes wastewater pollutant parameter data obtained through experiments at Udayana University's Analytical Laboratory. While the data of viscosity, specific gravity and weight of the volume of wastewater was obtained from the results of research at the Laboratory of Physical Chemistry of Udayana 
University. Wastewater viscosity data was obtained through an experiment using Ostwald viscometer. The magnitude of a liquid viscosity can be expressed using the Pioseulle or Pioseulle equation.

Equation 2.

$$
\eta=\frac{\pi \rho r^{4} t}{8 v l}
$$

or by multiplying the viscosity of the comparison liquid by comparison of the value of the liquid type and the time of the study results with the type and time of the comparative fluid research as in Equation 3.

Equation 3.

$$
\eta_{x}=\eta_{0} \frac{t_{x} x p_{x}}{t_{0} x p_{0}}
$$

One of the viscosity values that has been known is the pure water viscosity, which is 0.01008 Poisse or equivalent to $0.001008 \mathrm{Ns} / \mathrm{m}^{2}$.

Modeling in the Geo-Studio Seep/W software is a 2D cross-sectional model of the area to be analyzed. Analysis model was made at geometry distance $(0.0) \mathrm{cm},(0.100) \mathrm{cm},(100.40) \mathrm{cm},(50.40) \mathrm{cm},(50.30) \mathrm{cm},(45.30) \mathrm{cm}$, $(45.50) \mathrm{cm}$, and $(0.50) \mathrm{cm}$. The material model is conditioned to be saturated/unsaturated. Water is assumed to flow from the upstream to the downstream with the water level upstream made as high as $2 \mathrm{~cm}$, so that the boundary conditions at the upstream are $52 \mathrm{~cm}$. The analysis model was made with mesh or analysis area every $3 \mathrm{~cm}$ as in Figure 2.

The land data will be inputted to estimate the Volume of Water Content Function. Sandy soil and clay soil using the sample functions method and then selected material samples in the form of clay (sand) or sand (sand). While the hydraulic conductivity or seepage coefficient data will be used to estimate Hydraulic Conductivity Functions.

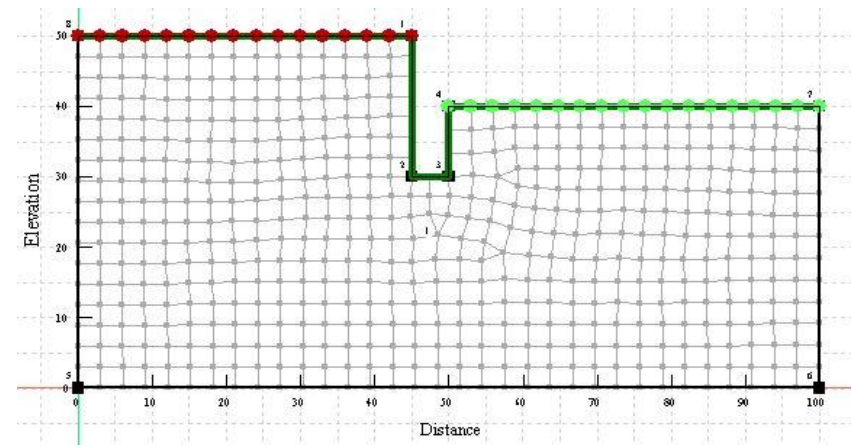

Figure 1. Analysis model with mesh area every $3 \mathrm{~cm}$

Aribudiman, I. N., Redana, I. W., Harmayani, K. D., \& Ciawi, Y. (2019). Seepage in soil from the difference of water viscosity using Geo-studio SEEP/W program. International Research Journal of Engineering, IT \& Scientific Research, 5(1), 15-26. https://doi.org/10.21744/irjeis.v5n1.586 


\section{Results and Discussions}

\subsection{Waste Quality Test Result}

Table 1

Liquid waste quality test results

\begin{tabular}{llllll}
\hline & & & & \multicolumn{2}{c}{ Result } \\
\cline { 4 - 6 } No & Parameter & Unit & Method & $\begin{array}{l}\text { Leachate } \\
\text { Cuwung }\end{array}$ & Waste \\
\hline 1. & COD (Chemical Oxygen Demand) & $\mathrm{mg} / \mathrm{L}$ & Titration & 3210.00 & 250.24 \\
2. & BOD (Biochemical Oxygen Demand) & $\mathrm{mg} / \mathrm{L}$ & Titration & 1506.20 & 137.15 \\
3. & Oil & $\mathrm{mg} / \mathrm{L}$ & Gravimetry & 480.00 & 56.00 \\
4. & TDS (Total Dissolved Solid) & $\mathrm{mg} / \mathrm{L}$ & Gravimetry & 10780.00 & 590.00 \\
5. & TSS (Total Suspended Solid) & $\mathrm{mg} / \mathrm{L}$ & Gravimetry & 237.91 & 0.58 \\
\hline
\end{tabular}

The results of the waste quality test from the analytical laboratory were then compared with the Minister of Environment Regulation No.5 of 2014 concerning wastewater quality standards as described in Table 2.

Table 2

Wastewater quality standards

\begin{tabular}{llll}
\hline No & Parameter & Unit & Highest Level \\
\hline 1. & COD (Chemical Oxygen Demand) & $\mathrm{mg} / \mathrm{l}$ & 100 \\
2. & BOD (Biochemical Oxygen Demand) & $\mathrm{mg} / \mathrm{l}$ & 50 \\
3. & TDS (Total Dissolved Solid) & $\mathrm{mg} / \mathrm{l}$ & 2000 \\
4. & TSS (Total Suspended Solid) & $\mathrm{mg} / \mathrm{l}$ & 200 \\
5. & Oil & $\mathrm{mg} / \mathrm{l}$ & 10
\end{tabular}

Source: Minister of Environment Regulation No.5 of 2014

Minister of Environment Regulation No.5 of 2014 provides limits on the quality of liquid waste to further be discharged into nature. However, the results on three types of waste, namely the Suwung landfill leachate waste and ceramics processing waste provide an illustration that these wastes should not be released directly or disposed of directly into the ground because they still contain pollutants that exceed the specified levels. Therefore, these wastes need to be processed in advance to reduce the level of pollution, after which they can be disposed of or released to the ground.

\subsection{Waste Viscosity Experiment Results}

Table 3

Liquid waste viscosity test results

\begin{tabular}{lll}
\hline No & Liquid Waste Type & Viscosity (N.s/m $\left.\mathrm{m}^{2}\right)$ \\
\hline 1. & Pure water & 0.001008000 \\
2.. & Ceramic Waste & 0.001366741 \\
3. & Leachate of Suwung & 0.002061309 \\
\hline
\end{tabular}

In Table 3, leachate from the Suwung landfill has a higher viscosity and the volume weight is also smaller than the ceramic waste. The various viscosity of liquid waste is influenced by the amount of dissolved material in the waste, such as TDS (Total Dissolved Solids) and the oil content in the waste. High TDS and oil in waste will produce greater waste viscosity. 
3.3 Groundwater Content

The soil sample used in this study is a sample of surface soil from the Ida Bagus Oka street, Denpasar. The results of the research on the moisture content of the samples of the native soil were not disturbed indicating the water content in the surface layer of the soil at Ida Bagus Oka street, Denpasar was $37.95 \%$.

\subsection{Specific Gravity and Weight of Waste Volume}

The specific gravity of a fluid is defined as the ratio between the density or density of a fluid to the density of water, while the weight of the volume is defined as the ratio between the weight and volume of the liquid itself. It is known that the density of water in general is $1000 \mathrm{~kg} / \mathrm{m}^{3}=1 \mathrm{ton} / \mathrm{m}^{3}=1 \mathrm{gr} / \mathrm{cm}^{3}$. The results of research on the specific gravity of waste are shown in Table 2.

Table 4

Liquid Waste Specific Weight

\begin{tabular}{lll}
\hline Liquid Waste Type & Specific gravity & $\begin{array}{l}\text { Volume weight } \\
\left(\mathrm{kN} / \mathrm{cm}^{3}\right)\end{array}$ \\
\hline Pure water & 0,999 & $9.8067 \times 10^{-6}$ \\
Ceramic waste & 0,991 & $9.7184 \times 10^{-6}$ \\
Leachate of Landfill & 0,976 & $9.5713 \times 10^{-6}$ \\
\hline
\end{tabular}

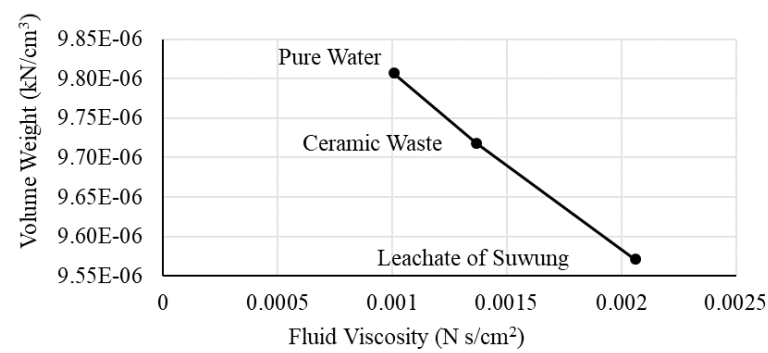

Figure 2. Graph of the relationship of viscosity and volume weight of the fluid.

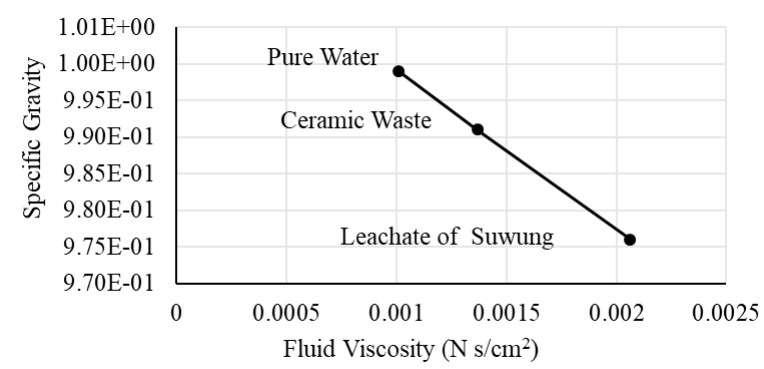

Figure 3. Relationship of viscosity and specific gravity of the fluid

In Figure 2 and Figure 3, it can be seen that the viscosity of a liquid will greatly affect the specific gravity and weight of the liquid volume itself. Figure 2. and Figure 3. shows that the higher the viscosity value of a fluid or liquid, the lower the weight value of the volume and weight of the type of liquid.

Aribudiman, I. N., Redana, I. W., Harmayani, K. D., \& Ciawi, Y. (2019). Seepage in soil from the difference of water viscosity using Geo-studio SEEP/W program. International Research Journal of Engineering, IT \& Scientific Research, 5(1), 15-26. https://doi.org/10.21744/irjeis.v5n1.586 


\subsection{Soil Specific Gravity}

Soil type gravity experiments (Gs) were also carried out on soil mixed with pure water (without waste), leachate from Suwung landfill and wastewater produced by the ceramic factory. The results are shown in Table 5.

Table 5

Soil Species Testing Results

\begin{tabular}{llll}
\hline \multirow{2}{*}{ Sample } & \multicolumn{2}{c}{ Specific Gravity of Mixed Soil } \\
\cline { 2 - 4 } & Pure water & Ceramic waste & $\begin{array}{l}\text { Leachate of } \\
\text { Suwung Landfill }\end{array}$ \\
\hline $\begin{array}{l}\text { Landsoil on Ida Bagus } \\
\text { Oka street, Denpasar. }\end{array}$ & 2.6619 & 2.5396 & 2.1871 \\
\hline
\end{tabular}

The results showed a decrease in soil specific gravity when soil was mixed with different types of waste. This can occur because the liquid wastes used in this study have a specific gravity smaller than the specific gravity of the soil tested.

\subsection{Soil Porosity}

Table 6

Soil Porosity Value

\begin{tabular}{llll}
\hline \multirow{2}{*}{ Sample } & \multicolumn{3}{c}{ Specific Gravity of Mixed Soil } \\
\cline { 2 - 4 } & Pure water & Ceramic waste & $\begin{array}{l}\text { Leachate of } \\
\text { Suwung Landfill }\end{array}$ \\
\hline $\begin{array}{l}\text { Landsoil on Ida Bagus Oka } \\
\text { street, Denpasar. }\end{array}$ & $51.20 \%$ & $50.03 \%$ & $46.30 \%$ \\
\hline
\end{tabular}

The calculation results in Table 4 show that there is a decrease in the value of soil porosity due to the addition of waste. The decrease in the value of soil porosity causes the pores of the soil to shrink so that it will cause the increase in soil density.

\subsection{Soil Hydraulic Conductivity}

The value of hydraulic conductivity is very important in the analysis of seepage of a liquid in a soil layer. Therefore, this study also includes the value of hydraulic conductivity as one of the parameters to be inputted in the Geo-Studio Seep/W. The results of the study are shown in Table 5.

Table 7

Soil Hydraulic Conductivity

\begin{tabular}{llll}
\hline \multirow{2}{*}{ Sample } & \multicolumn{3}{c}{ Hydraulic Conductivity of Soil Mixed with various type of Liquid } \\
\cline { 2 - 4 } & Pure Water $(\mathrm{cm} / \mathrm{s})$ & Ceramic waste $(\mathrm{cm} / \mathrm{s})$ & $\begin{array}{l}\text { Leachate of Suwung } \\
\text { Landfill }(\mathrm{cm} / \mathrm{s})\end{array}$ \\
\hline Landsoil on Ida Bagus & 0.0018949 & 0.0012 & 0.0001191 \\
Oka street, Denpasar & 0.002003 & 0.0010 & 0.0000866 \\
\hline Average & 0.001949 & 0.0011 & 0.0001029 \\
\hline
\end{tabular}


3.8 Results of Seepage Analysis Using Geostudio Seep/W

The viscosity or viscosity value of a liquid is inversely proportional to the value of its hydraulic conductivity. This means that the higher the viscosity value of a liquid, the lower the value of hydraulic conductivity as shown in Figure 4.

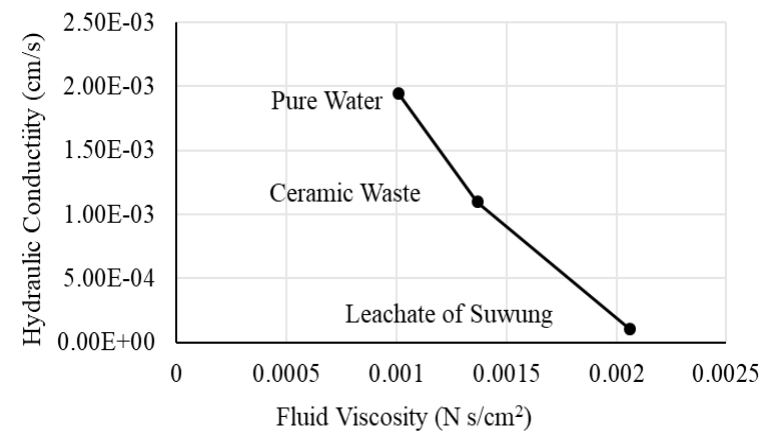

Figure 4. Graph of Viscosity and Hydraulic Conductivity Relations

\subsection{Geostudio See/ W Data Input}

The analysis model created in Geo-Studio Seep/W is in saturated/unsaturated conditions, which means that the model made is not always flooded with water or pollutants. This is considering the presence of rain which does not always occur at any time so that the soil still has the opportunity to absorb water into it. Some parameters included in the analysis model at Geo-Studio Seep/W are shown in Table 9.

Table 9

Geostudio Seep/W Data Input

\begin{tabular}{|c|c|c|}
\hline Data Input & & $\begin{array}{l}\text { Soil on Ida Bagus Oka, } \\
\text { Denpasar street }\end{array}$ \\
\hline \multirow{3}{*}{$\begin{array}{l}\text { The volume of } \\
\text { water }\left(\mathrm{kN} / \mathrm{cm}^{3}\right)\end{array}$} & Pure water & $9.8070 \times 10^{-6}$ \\
\hline & Ceramic waste & $9.7184 \times 10^{-6}$ \\
\hline & $\begin{array}{l}\text { Leachate of } \\
\text { Suwung }(\mathrm{cm} / \mathrm{s})\end{array}$ & $9.5713 \times 10^{-6}$ \\
\hline \multicolumn{3}{|c|}{ Volume Water Content Function } \\
\hline \multirow{3}{*}{ Soil Porosity } & Pure water & $51.20 \%$ \\
\hline & Ceramic waste & $50.03 \%$ \\
\hline & $\begin{array}{l}\text { Leachate of } \\
\text { Suwung }\end{array}$ & $46.30 \%$ \\
\hline \multicolumn{3}{|c|}{ Hydraulic Conductivity Functions } \\
\hline \multirow{3}{*}{$\begin{array}{l}\text { Hydraulic } \\
\text { Conductivity } \\
(k x)\end{array}$} & Pure water & 0.0019490 \\
\hline & Ceramic waste & 0.0011000 \\
\hline & $\begin{array}{l}\text { Leachate of } \\
\text { Suwung Landfill }\end{array}$ & 0.0001029 \\
\hline
\end{tabular}

Calculation results obtained from the analysis using Geo-Studio Seep/W is the water discharge rate through the porous media. Calculation of the rate of a fluid passing through the soil medium (seepage speed/infiltration) was done by using Equation 4.

$$
\mathrm{v}=\mathrm{Q} / \mathrm{A}
$$

with the total area of soil media in the analysis, model was $4400 \mathrm{~cm}^{2}$.

Aribudiman, I. N., Redana, I. W., Harmayani, K. D., \& Ciawi, Y. (2019). Seepage in soil from the difference of water viscosity using Geo-studio SEEP/W program. International Research Journal of Engineering, IT \& Scientific Research, 5(1), 15-26. https://doi.org/10.21744/irjeis.v5n1.586 


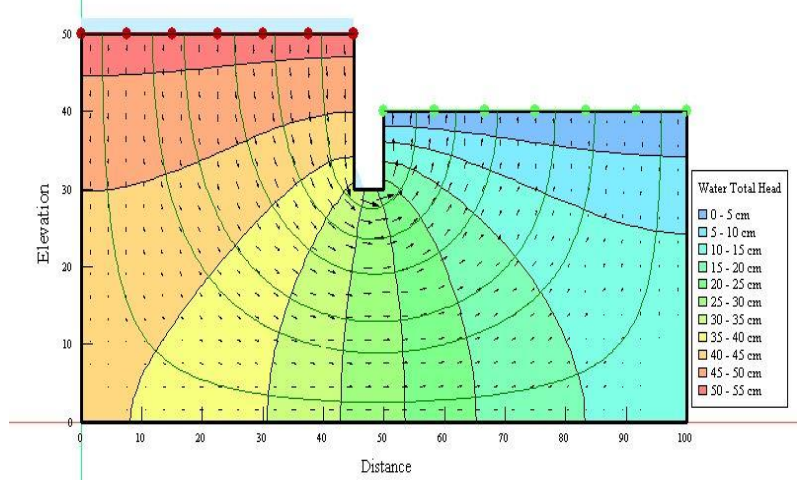

Figure 5. Modeling results of the soil at Ida Bagus Oka street, Denpasar, with pure water/not waste

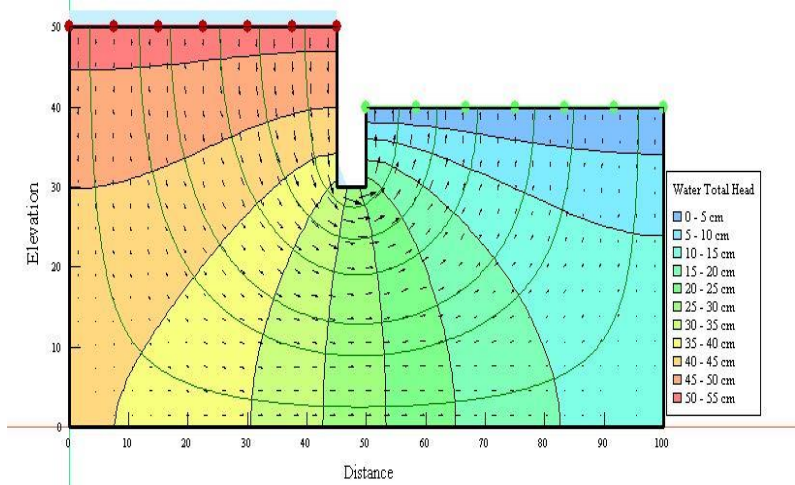

Figure 6. Modeling results of the soil on Ida Bagus Oka Street, Denpasar, with waste from the processing of ceramics

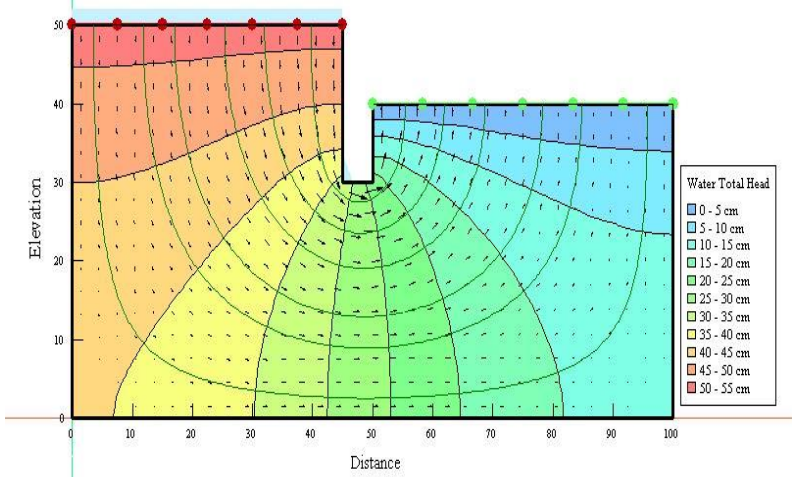

Figure 7. Modeling results of land on Ida Bagus Oka Street, Denpasar, with leachate waste from the Suwung landfill

Figure 5, Figure 6, and Figure 7 are the results of modeling soil media with several types of waste and without waste using GeoStudio Seep/W indicating the existence of equipotential lines and flow lines which indicate the movement of water from the water source in the upstream to the downstream. While the color gradation in the modeling results shows the stress that occurs due to the water pressure in the upstream part. The upstream water pressure will press and drain water from upstream to downstream or from a place that has a high elevation to a place that has a low elevation. The red color on the modeling results shows the part of the land that experiences the greatest stress due to the influence of water in the upstream, while the dark blue shows the part of the land that experiences the least stress. 
Table 10

Seepage discharge and seepage speed in the soil

\begin{tabular}{lll}
\hline \multirow{2}{*}{ Fluid Type } & \multicolumn{2}{c}{ Soil on Ida Bagus Oka Street, Denpasar } \\
\cline { 2 - 3 } & $\begin{array}{l}\text { Seepage discharge } \\
\left(\mathrm{cm}^{3} / \mathrm{s}\right)\end{array}$ & $\begin{array}{l}\text { Flow Speed } \\
(\mathrm{cm} / \mathrm{s})\end{array}$ \\
\hline $\begin{array}{l}\text { Pure water } \\
\text { Ceramic waste }\end{array}$ & 0.3840 & $8.727 \times 10^{-5}$ \\
Leachate of & 0.2710 & $4.932 \times 10^{-5}$ \\
Suwung Landfill & 0.0204 & $4.636 \times 10^{-6}$ \\
\hline
\end{tabular}

The results in Table 7 explain that the type of fluid that flows through the soil media affects the seepage speed and the amount of water that can be passed through the soil. This happens because of the different hydraulic conductivity values, the higher the viscosity value of a fluid, the lower the value of the hydraulic conductivity of the soil so that the ability of the soil to pass water will also be lower. The relationship between the viscosity of the research sample with remebeate discharge in the soil is shown in Figure 8.

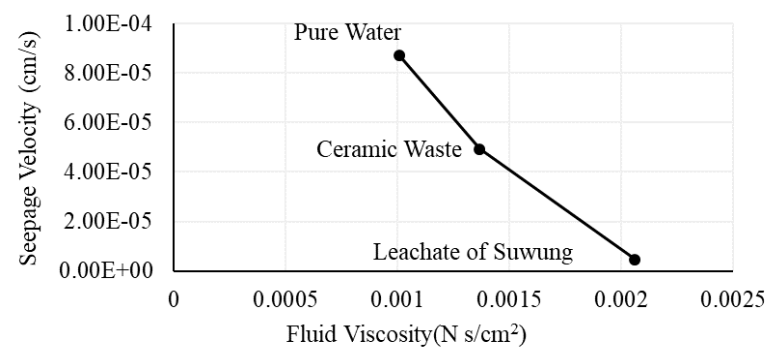

Figure 8. The relationship between fluid viscosity and seepage velocity

Figure 9 shows that the soil that is drained with water (without waste) has the largest seepage discharge rate compared to the soil drained with wastewater. The latter has a greater viscosity than pure water. If expressed in terms of percentage, the amount of decrease in seepage discharge rate or seepage speed in silty sandy land on Ida Bagus Oka street, Denpasar, on seepage discharge or seepage speed due to pure water is $70.573 \%$ and $5.313 \%$ respectively. The relationship between seepage discharge rate and seepage velocity in the soil is shown in Figure 9.

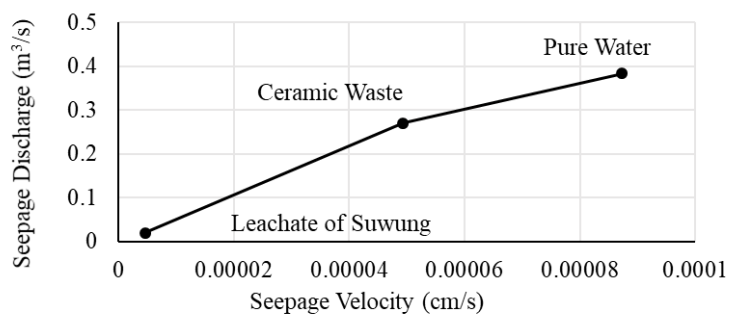

Figure 9. The relationship between seepage discharge rate (Q) to the seepage velocity (v) silty sandy soil on Ida Bagus Oka street, Denpasar.

Figure 9 shows that the seepage speed is directly proportional to the seepage discharge in the soil. This means that the more seepage discharge through a soil medium at a certain time, the faster the fluid through the soil media. Likewise on the contrary, if the resulting seepage discharge is small, the rate of seepage of fluid will be even lower.

Aribudiman, I. N., Redana, I. W., Harmayani, K. D., \& Ciawi, Y. (2019). Seepage in soil from the difference of water viscosity using Geo-studio SEEP/W program. International Research Journal of Engineering, IT \& Scientific Research, 5(1), 15-26. https://doi.org/10.21744/irjeis.v5n1.586 


\section{Conclusion}

The conclusions obtained from this study are as follows; Viscosity value of ceramic waste and leachate waste of Suwung landfill has a viscosity of $0.001366741 \mathrm{~N} \mathrm{~s} / \mathrm{m}^{2}$ and $0.002061309 \mathrm{~N} . \mathrm{s} / \mathrm{m}^{2}$ respectively. The viscosity of fluid affects the value of soil hydraulic conductivity. As a result of mixing with wastewater, the soil hydraulic conductivity value also decreases. The value of soil hydraulic conductivity decreased from $0.001949 \mathrm{~cm} / \mathrm{s}$ to $0.0001029 \mathrm{~cm} / \mathrm{s}$ for silty sand soil. The magnitude of the effect of changes in seepage discharge or sand seepage speed on Ida Bagus Oka street, Denpasar, due to the drainage of ceramic wastewater and leachate from Suwung landfill to seepage discharge or the rate of seepage of pure water are $70.573 \%$ and $5.313 \%$ respectively.

\section{Conflict of interest statement and funding sources}

The authors declared that they have no competing interest. The study was financed by personal funding.

\section{Statement of authorship}

The authors have a responsibility for the conception and design of the study. The authors have approved the final article.

\section{Acknowledgments}

The authors would like to thank the Head of the Civil Engineering Department at the Faculty of Engineering at Udayana University, The Head of the Soil Mechanical Engineering Laboratory of the Civil Engineering Department at the Faculty of Engineering at Udayana University and the parties who supported so that this paper could be completed. 


\section{References}

Bakhshipour, Z., Asadi, A., Huat, B. B., Sridharan, A., \& Kawasaki, S. (2016). Effect of acid rain on geotechnical properties of residual soils. Soils and Foundations, 56(6), 1008-1020. https://doi.org/10.1016/j.sandf.2016.11.006

Ghobadi, M. H., Abdilor, Y., \& Babazadeh, R. (2014). Stabilization of clay soils using lime and effect of $\mathrm{pH}$ variations on shear strength parameters. Bulletin of Engineering Geology and the Environment, 73(2), 611-619. https://doi.org/10.1007/s10064-013-0563-7

Hardiyatmo, H. C. (2012). Tanah Longsor dan Erosi: Kejadian dan Penanganan.

Huang, F. X., \& Lu, H. J. (2014). Experiment Study on the Atterberg Limits of Clay Contaminated by Oil. http://www.ejge.com/2014/Ppr2014.294ma.pdf

Nair A.S. \& Philip G.J. (2016). Effect of pH Variation of pore fluid on The Geotechnical Properties of Fly Ash Stabilized Clay, International Journal of Science ang Research (IJSR), 5(9).

Olgun, M., \& Yildiz, M. (2012). Influence of acetic acid on structural change and shear strength of clays. Iranian Journal of Science and Technology. Transactions of Civil Engineering, 36(C1), 25. http://ijstc.shirazu.ac.ir/mobile/article_643.html

Prakash, S., Chakrabarty, T., Singh, A. K., \& Shahi, V. K. (2013). Polymer thin films embedded with metal nanoparticles for electrochemical biosensors applications. Biosensors and Bioelectronics, 41, 43-53. https://doi.org/10.1016/j.bios.2012.09.031

Rahman, M. M., \& Nahar, T. T. (2015). Effect of pH on Shear Strength Behavior of Granular Soil. Global Journal of Research In Engineering. https://engineeringresearch.org/index.php/GJRE/article/view/1279

Reddy, P. H. P., \& Sivapullaiah, P. V. (2010). Effect of alkali solution on swell behavior of soils with different mineralogy. In GeoFlorida 2010: Advances in Analysis, Modeling \& Design(pp. 2692-2701). https://doi.org/10.1061/41095(365)273

Sen, P., Shah, P. P., Nativio, R., \& Berger, S. L. (2016). Epigenetic mechanisms of longevity and aging. Cell, 166(4), 822-839. https://doi.org/10.1016/j.cell.2016.07.050

Spagnoli, G., Rubinos, D., Stanjek, H., Fernández-Steeger, T., Feinendegen, M., \& Azzam, R. (2012). Undrained shear strength of clays as modified by $\mathrm{pH}$ variations. Bulletin of Engineering Geology and the Environment, 71(1), 135-148. https://doi.org/10.1007/s10064-011-0372-9

Sunil, B. M., Nayak, S., \& Shrihari, S. (2006). Effect of pH on the geotechnical properties of laterite. Engineering geology, 85(1-2), 197-203. https://doi.org/10.1016/j.enggeo.2005.09.039

Tajnin, R., Abdullah, T., \& Rokonuzzaman, M. D. (2014). Study on the salinity and pH and its effect on geotechnical properties of soil in south-west region of Bangladesh. International Journal of Advanced Structures and Geotechnical Engineering, 3(2), 138-147.

Van Olphen, H., \& Hsu, P. H. (1978). An introduction to clay colloid chemistry. Soil Science, 126(1), 59.

Wesley, L. D. (1977). Mekanika Tanah. Badan Penerbit Pekerjaan Umum.

Yong, R. N., Mohamed, A. M. O., \& Warkentin, B. P. (1992). Principles of contaminant transport in soils. Elsevier Science Publishers. https://www.cabdirect.org/cabdirect/abstract/19931974865

Yunus, N. M., Wanatowski, D., \& Stace, L. R. (2011). Effect of humic acid on physical and engineering properties of lime-treated organic clay. Engineering and Technology, 59(201), 1. https://www.waset.org/publications/2800

Aribudiman, I. N., Redana, I. W., Harmayani, K. D., \& Ciawi, Y. (2019). Seepage in soil from the difference of water viscosity using Geo-studio SEEP/W program. International Research Journal of Engineering, IT \& Scientific Research, 5(1), 15-26. https://doi.org/10.21744/irjeis.v5n1.586 


\section{Biography of Authors}

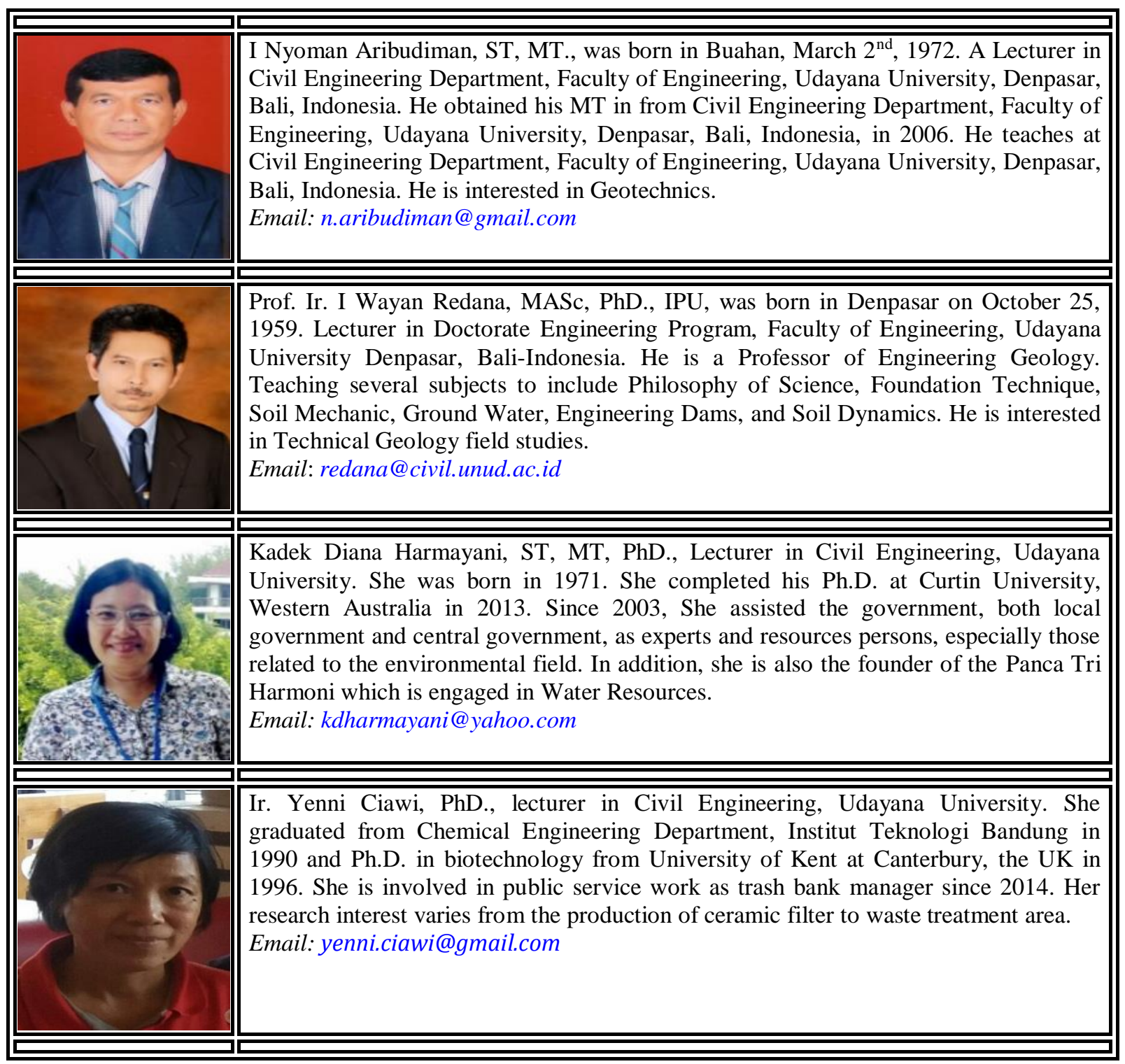

